\title{
Utilization Of Scientific Publication Media To Improve The Quality Of Scientific Work
}

Author Notification 9 July 2019

Final Revised 21 October 2019

Qurotul Aini ${ }^{1}$, Indri Handayani ${ }^{2}$, Fauziyyah Husna Nurdiayanah Lestari ${ }^{3}$

1,2,3 University of Raharja, JL. Jenderal Sudirman No.40 Modern Cikokol Tangerang e-mail: aini@raharia.info, indri@raharja.info, fauziyyah@raharja.info
Published

24 December 2019

To cite this document:

Aini, Q., Handayani, I., \& Nurdiayanah Lestari, F. (2019). Utilization Of Scientific Publication Media To Improve The Quality Of Scientific Work. Aptisi Transactions On Management (ATM), $4(1), 1-12$.

DOI:

https://doi.org/10.33050/atm.v4i1.711

\begin{abstract}
The publication of scientific work is an absolute thing that must be owned and produced by academics at this time. Moreover, when referring to the Minister of Administrative and Bureaucratic Reform (PAN RB) Regulation No. 17 of 2013 and the Minister of Education and Culture Regulation No. 92 of 2004 which states that the increase in the academic level of lecturers requires publication of accredited national scientific journals and journals internationally reputable in their field. In addition to being very important for the performance of lecturers, the publication of scientific papers has become a government regulation through the Director General of Higher Education, which requires S1, S2 and S3 students to make a summary of scientific work published both online and in print as one of the graduation requirements. Seeing this, Raharja College has participated in providing publication media for scientific works, especially in online forms, one of which is iLearning Journal Center (iJC). Until now iLearning Journal Center has overseen 5 (five) journals in it with different scope of research. However, the problems that occur at this time are still a lack of the general public to know especially in the Higher Education environment regarding the iLearning Journal Center (iJC) as a publication media for online scientific work. In this study will be discussed about the steps or methods taken to maximize the use of iLearning Journal Center (iJC) as an online journal publication media to improve the quality and quantity of scientific works. This study uses SWOT analysis method and system design using the Unified Modeling Language (UML) and the applications used in this study by applying the Open Journal System (OJS) which is known as management software and publishing online journals. The results of this study are a governance or management that can be done as a step to maximize the increase of publication of online scientific works for the academic community.
\end{abstract}

Keywords: iLearning Journal Center (iJC), Scientific Work Publication, Journal Online, Open Journal System (OJS)

\section{Introduction}

Scientific work is something that is still a measure of value and guidance on the basis of research that has been carried out by academics, especially students and lecturers. One scientific work in the form of this research can be made in the form of a journal. The results of the study in the form of this journal are still points or values of the quality of lecturers or students in performing their performance [1]. Which means that the more scientific papers or journals produced by the lecturers, the better the lecturers' performance value can be proven by the research and research conducted by the lecturer in the form of a journal. This journal is not only important for lecturers in every university, but it is also very important for students and final year students at every state and private tertiary institution as one of their graduation requirements. This is reinforced by government regulations through a circular issued by the Director General of Higher Education which requires students or undergraduates who are studying $\mathrm{S} 1, \mathrm{~S} 2$ or $\mathrm{S} 3$ to make a summary of scientific work 
and can be published in both online and printed journals [2]. This scientific work in the form of a journal that has been published or published is certainly not only a prerequisite for graduation but is also very useful for the future of the Indonesian people in exploring science and looking for relevant, accurate and updated references.

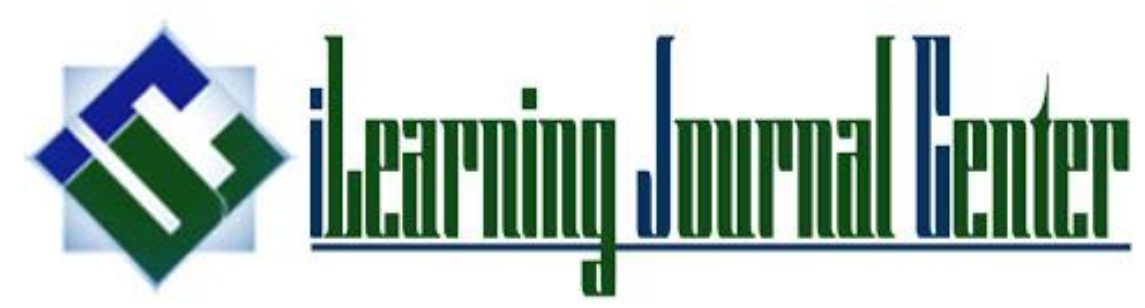

Figure 1. Logo of iLearning Journal Center

iLearning Journal Center (iJC) is one of the publication media for online-based scientific works that are currently owned and applied by Raharja College. In the iLearning Journal Center (iJC) system there are currently 5 (five) journals in it including Technomedia Journal (TMJ), Journal Mozaik which is obtained in collaboration with STISIP Yuppentek Tangerang, STT Yuppentek Journal obtained in collaboration with STT Yuppentek Tangerang, Aptisi Transactions of Management (ATM) a scientific journal published by APTISI (Association of Indonesian Private Universities) and Aptisi Technology Journal (ATJ). Where each journal has a different scope for scientific articles that will be received. For now the iLearning Journal Center (iJC) system has implemented and used the Open Journal System (OJS) version 3.1 application where this has been upgraded from the previous version 2.0.

In order to maximize the utilization of the iLearning Journal Center (iJC) system in Raharja College, the relation is as a publication media for scientific work that has been based online, so it is necessary to socialize it to the academic community especially in the Raharja College environment regarding the system of managing scientific works in the form of journals using the application Open Journal System (OJS). In addition to providing knowledge and direction to university students, Raharja, knowledge of the procedures for managing scientific works also needs to be embedded in each of the roles that participate in the management process of this journal [3]. At this time it can be said that the level of interest of students in making scientific works in the form of this journal is not working optimally. Besides the difficulty of finding problems that will be used as objects of research, the process of publishing online journals is also lacking. Therefore the importance of knowledge for them in using and utilizing the publication media of scientific works such as the Open Journal System (OJS) application is to be carried out further processes related to scientific papers or journals that they have made so that they can be published or published [4].

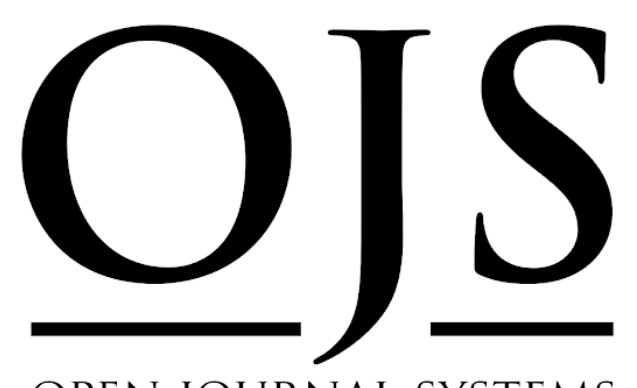

OPEN JOURNAL SYSTEMS

Figure 2. Open Journal System (OJS)

In the iLearning Journal Center (iJC) system which is currently being used as a publication media for online-based scientific works, the application of Open Journal System (OJS) application or software is used. This Open Journal System (OJS) is devoted as an 
application for managing and publishing scientific papers in the form of online journals. The management procedures until the process of publishing scientific papers or journals are already available in a coherent manner in this Open Journal System (OJS) application. Only each part carries out its role according to the established procedures. This Open Journal System (OJS) was developed by a company called Public Knowledge Project (PKP) which has now released its newest application version. Likewise with the iLearning Journal Center (iJC) system which is currently implementing the Open Journal System (OJS) version 3.1 application that is different from the previous system. It is expected that by upgrading the current system version the management process to publishing online journals becomes easier and more effective [5].

\section{Research Method}

This research is basically a way that can be done to collect data in the form of facts and information for further analysis.

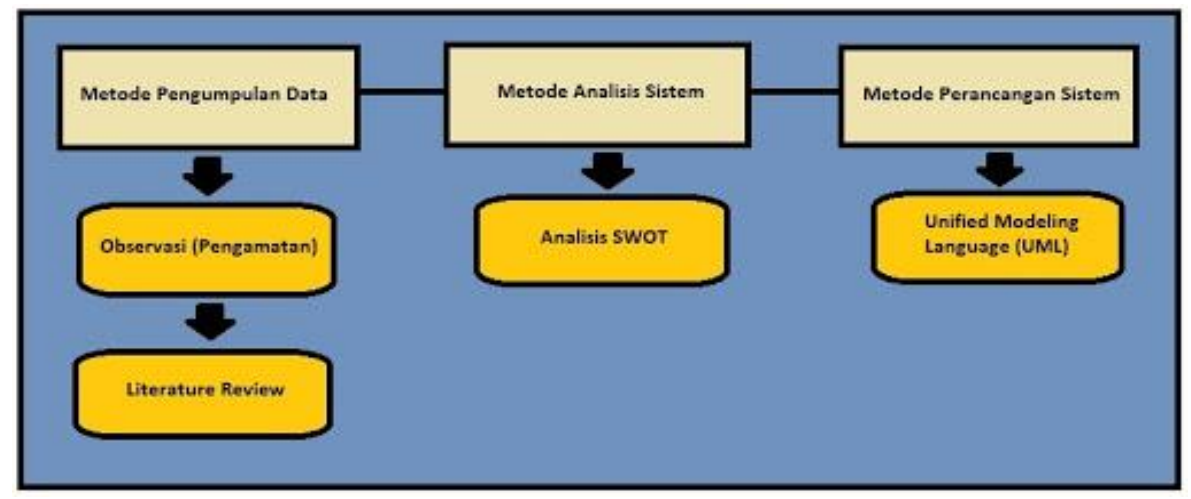

Figure 3. Research Methods

As for this research, data collection methods used are observation or direct observation in the REC (Raharja Enrichment Center) room where the development and utilization of the iLearning Journal Center (iJC) system is carried out. For the system analysis method itself, it uses SWOT analysis techniques by maximizing strengths (weaknesses), weaknesses (opportunities), opportunities (opportunities), and threats (threats) to the use of the iLearning Journal Center (iJC) system. As for the system design method itself by applying the Unified Modeling Language (UML) tools using Microsoft Visual Paradigm software.

In this study also used literature study method or literature review by gathering several theories of knowledge obtained from previous studies that are relevant to this study. The following are 7 (seven) lists of literature reviews used in this study as reference material to maximize the use of online-based scientific publication media:

1. Research conducted by Nurlaila Suci Rahayu Rais, Ruli Supriati, and Siti Ika Danti from Raharja College in 2018 entitled "Installation of Open Journal System (OJS) Version 3 as Supporting Management Activities and Scientific Journal Publications". In this research they discussed the advantages of the Open Journal System (OJS) version 3 software and the procedure for installing Open Journal System (OJS) to find out the management of electronic scientific journal (e-journal) publications. In this research they also discussed the advantages of OJS version 3, which included the enhanced user interface when compared with the previous version, the workflow in the OJS version 3 system is very dynamic and easy to use so it doesn't confusing each of the roles in charge, having a more flexible user role and more themes available that can be tailored to the needs. So that with the use of the Open Journal System (OJS) version 3 system, it provides more convenience in management activities to the publication of scientific journals online [6].

2. Research conducted by Indri Handayani, Qurotul Aini, and Novita Sari from Raharja College in 2018 entitled "Utilization of OJS-Based iJC System as E-Journal Media in Yuppentek STISIP". In this research they discussed the implementation of the management of an online journal based on STISIP Yuppentek by utilizing the system in the iLearning Journal Center (iJC) by applying the Open Journal System (OJS). With the implementation of the online journal system (e-journal) on Yuppentek STISIP, it is expected that the scientific journal management system 
can provide convenience for writers who will submit their journals more easily, quickly, saving time, cost and energy. So that all the process of publishing the manuscript from the start of submission of scientific journal manuscripts, editing stage, review stage, copyediting stage until the production stage is more systematically carried out [7].

3. Research conducted by Wahyudin Darmalaksana and Yaya Suryana from UIN Sunan Gunung Djati Bandung in 2018 entitled "Correspondence in Scientific Publications". In this research they discussed the publication and correspondence techniques of scientific publications so that the results of the research could be published properly in accordance with the template and the scope of the research that had been determined. With the good and correct correspondence, the flow of delivery to the publication of articles in accordance with the expectations of the author and also the journal manager starts from the submission of articles by the author, submission of the results of the revision from the reviewer, delivery of corrected revisions from the authors who are entirely online-based using the Open Journal System (OJS ) The results of this study state that the importance of correspondence factors in the publication of scientific papers to facilitate the improvement of the quality and quantity of papers published in online journals. In scientific publications, especially in online-based journals, there is a need for correspondence between the author and the journal manager so that the needs and desires of the author can run synchronously and the writer can easily understand the flow of the article submission and the revised delivery [8].

4. Research conducted by Wahyudin Darmalaksana from UIN Sunan Gunung Djati Bandung in 2018 entitled "Organizing Agency for Publication of Research Results". In the research that has been done, it discusses the results of the trial of the publication of scientific articles which turned out to be very effective through the organization responsible for publication. Where does it mean that a scientific article of research results which includes collaboration in it between the main author, correspondent writer, co-author, and research leader (research leader) can be ascertained the publication of research results will be realized. In this study also confirmed that how important the publication of scientific articles that make the results of the study not only pile up so that with this publication the results of these studies can be known or read by others and get more benefits for the people. Therefore in order to realize the scientific article successfully to be published it is necessary to have a mature and well-planned research concept from some of the writers involved in it which is said to be the organization responsible for the publication of research results [9].

5. Research conducted by Moh Yamin from Lambung Mangkurat University in Banjarmasin in 2018 entitled "Literacy Policy to Increase Publication Productivity in Higher Education". In the research that has been done, it discusses the need for higher education to encourage each lecturer to publish scientific work in order to revive the academic atmosphere and also as a manifestation of the implementation of higher education tridharma. In this study also explained the most important things that need to be considered by the leaders of universities that the publication of scientific works on these lecturers cannot stand alone because it requires and requires a commitment and higher education policy synergistically and sustainably. Therefore, the existence of a literacy policy in universities is very helpful for lecturers to continue to be active and productive in the field of publication [10].

6. Research conducted by Untung Rahardja, Indri Handayani, and Randy Wijaya from Raharja College in 2018 entitled "Application of Viewboard Technomedia Journal Using the iLearning Journal Center System in Higher Education". In their research they discussed the making of Technomedia Journal (TMJ) viewboard which was used to provide all the updated and informative information related to things such as the number or total users registered in the Technomedia Journal (TMJ), the total journal author or author has registered in Technomedia Journal (TMJ), the total number of reviewers, the total number of editors, and the total number of papers or scientific articles entered in the Technomedia Journal (TMJ). All information regarding data relating to Technomedia Journal (TMJ) will be presented and valid in the Technomedia Journal (TMJ) viewboard. In this study also explained by the presence of this viewboard makes it easy for administrators to monitor all information in Technomedia Journal (TMJ) [11].

7. Research conducted by Manihar Situmorang and Kawan Sihombing from the State University of Medan in 2018 entitled "Strategies for Preparing Article Manuscripts Good for Publication in Reputable Scientific Journals". In their research they discussed strategies or steps prepared to make scientific articles or manuscripts to be sent to reputable scientific journals. There are several writing standards that must be prepared so that the articles can be said to be published in reputable scientific journals such as language and grammar, format, original writing, novelty

ATM Vol.4, No. 1, January $2020: 1-12$ 
of discussion material, and scientific contributions that are required by the article to be assessed as qualified manuscripts. In this study also explained that another important component as an assessment is the presentation of articles in the form of pictures, diagrams, graphs, tables or illustrations and so on in writing articles to be published in reputable scientific journals. In addition to these factors in terms of originality and scientific contributions in the article, it is also the main assessment so that the writings sent can be received and published in reputable scientific journals [12].

From the seven discussion of literature review above, it can be concluded that the use of Open Journal System (OJS) software is considered as the right choice in building a media for online scientific article management. Considering that academics, both lecturers and students, are required to write scientific articles from their research and can be published so that they are useful for many people and as a form of tridharma service to a university. This is certainly strengthened by the rules issued by the Director General of Higher Education. With the existence of an onlinebased scientific article publication media, it is expected that it will improve the quality and quantity of scientific articles that will be published because the use of the Open Journal System (OJS) application that is quite effective and efficient in handling it is all supported by understanding and knowledge of each role involved in the management of scientific journals. Besides that there are also several other factors that make this scientific article feasible to be published such as the originality of the issues raised in the discussion, the level of scientific contributions contained in the article, the use of language and grammar, the novelty of the discussion material and so forth [13]. In addition, strong intentions and careful preparation for each correspondence in writing scientific articles are also factors that can be assessed so that a scientific article can be published in the form of a journal.

\section{Results and Analysis}

\subsection{Analysis of Problems}

As previously explained that at present scientific work or research results, whether research results from lecturers or students who are taking academic education are required to write down and publish the results of their research. Publication of the scientific work can also be said as an assessment related to performance that can be directly seen and proven through a study [14]. Obligations related to the publication of this scientific work were also strengthened by the Minister of Administrative Reform and Bureaucratic Reform (PAN RB) No. 17 of 2003 and the Minister of Education and Culture Regulation No. 92 of 2014 which states that the increase in lecturer position is one of the factors, namely publishing or publishing results research in accredited national scientific journals and reputable international journals in their fields [15]. The publication of this scientific work is currently being carried out both from within the University of Raharja itself and from outside. At Raharja College, there are currently a number of scientific journal publication media conducted online in accordance with the Director General of Higher Education regulations that use the Open Journal System (OJS) [16]. One of the online scientific journal publication media is in iLearning Journal Center (iJC) in which there are 5 (five) journals with different scope. However, there are still a number of issues currently in the management of scientific publications that use the Open Journal System (OJS) system, especially by authors and parties (roles) who are directly involved in the management process of the scientific journal.

The process of managing revenue until the publication of scientific articles in the form of this journal uses the Open Journal System (OJS) software which currently on the iLearning Journal Center (iJC) system has implemented the latest version 3.1. Where in this latest version has the advantages of the previous version, especially in the scientific journal processing stage by step [17]. Starting from the display on the author's page, the editor's page display, as well as the view on the reviewer page. So if you know the overall flow of the steps in the Open Journal System (OJS), the process of managing scientific journals becomes more effective and efficient. However, the problems that arise at this time there are several roles that still do not understand the performance and flow that exist in the Open Journal System (OJS) either from the authors of the scientific work (author), the editor, or the reviewer itself. So that the process of managing scientific journals tends to be slow and can even exceed the publication or publishing deadline from a predetermined time [18]. This is because the scientific manuscripts or journals that accumulate in the queue can be caused by a lack of understanding of the flow of the scientific journal processing process. With the existence of these problems, in this study will be described and explained the page view of 
each role in relation to the management of scientific journals in the Open Journal System (OJS) both on the page display of the author, journal manager, journal editor, and reviewer in order to maximize the use of the iLearning Journal Center (iJC) system as an online-based scientific publication media which is expected to improve the quality and quantity of publication of scientific papers in the form of journals [19].

\subsection{Troubleshooting}

After observing and testing related to the process and management flow of scientific journals in the Open Journal System (OJS) version 3.1, this research will explain and display the sections of each work process page from the author, editor page. and related reviewers in the management of this scientific journal. The alternative is to provide knowledge in the form of a general description of what the work process or flow is applied to this Open Journal System from starting receipt of articles of scientific work, checking by reviewers, acceptance of revised results until the article is ready to enter the production stage until it is published [20]. With a good understanding of the flow of the scientific journal publication work process, it is expected that media management of online-based scientific journals that exist in Raharja College can be implemented to the maximum extent possible so as to minimize delays in publishing scientific journals and improve the quality and quantity of published scientific works [21].

\subsection{Program Listing}

Program listing from the iLearning Journal Center (iJC) system that implements Open Journal System (OJS) software is a collection of programming codes used to build and design the appearance of the iLearning Journal Center (iJC) system. Where on the initial display the website is directed directly to the iJC system's homepage which provides a description of the iJC itself. Then there is a menu in the header including iJC Home, About Us, Login and Register. In addition there is a search column facility to quickly search for journals in the iLearning Journal Center (iJC) [22]. Following are some program codes from the iLearning Journal Center (iJC) page view:

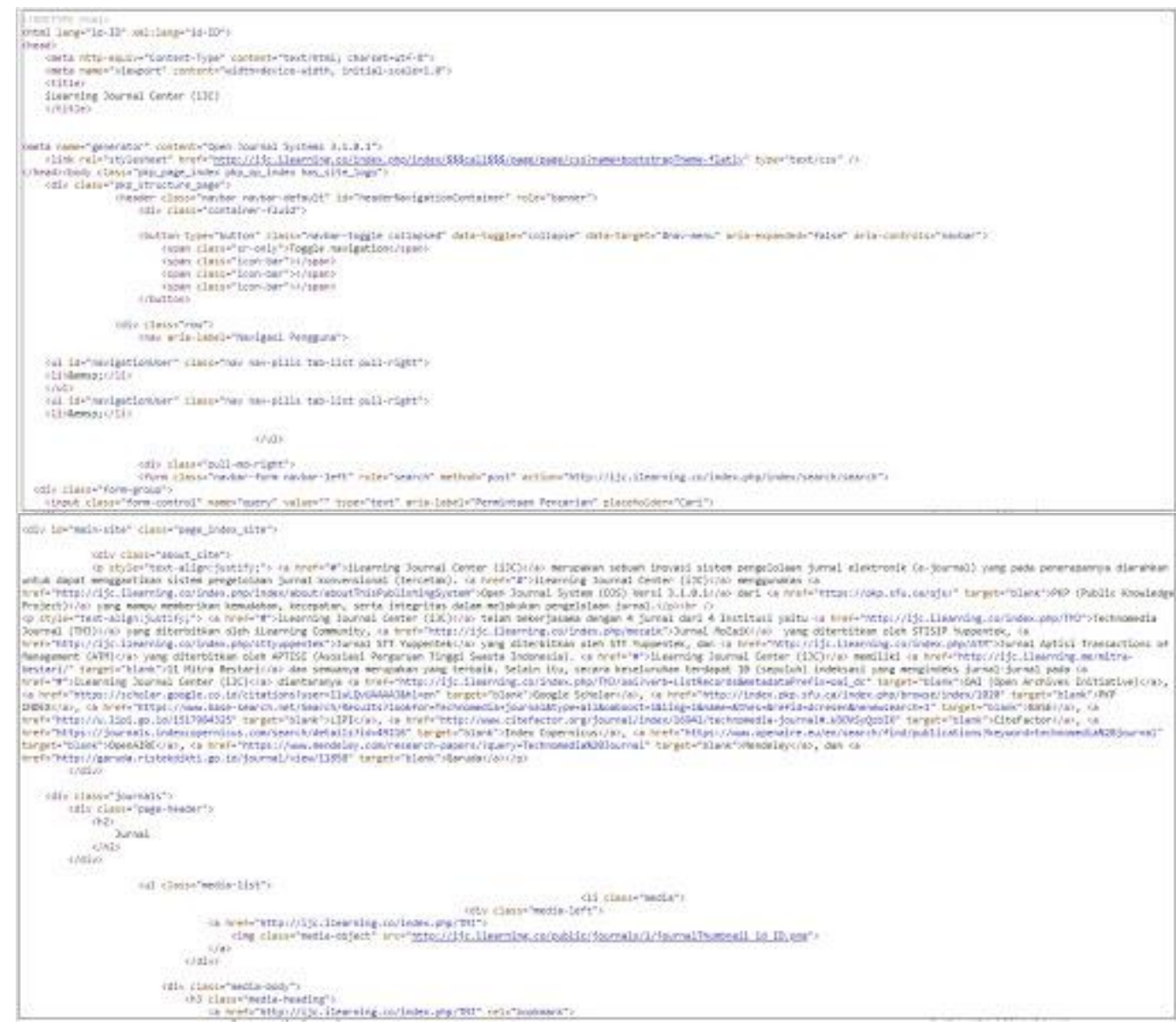




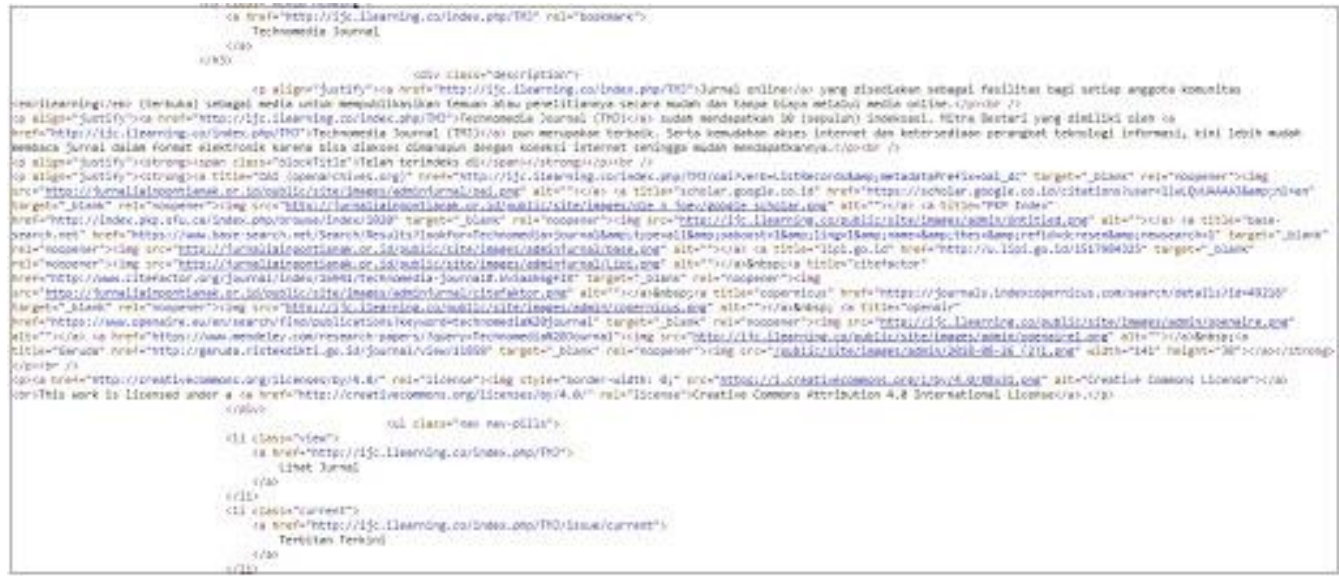

\subsection{Implementation}

In this implementation section, each page will display the roles in the management flow of online-based scientific journals using the Open Journal System (OJS) in relation to the management process of the management and publication of online scientific papers in the form of journals [23].

\section{Di splay of Journal Admin Pages}

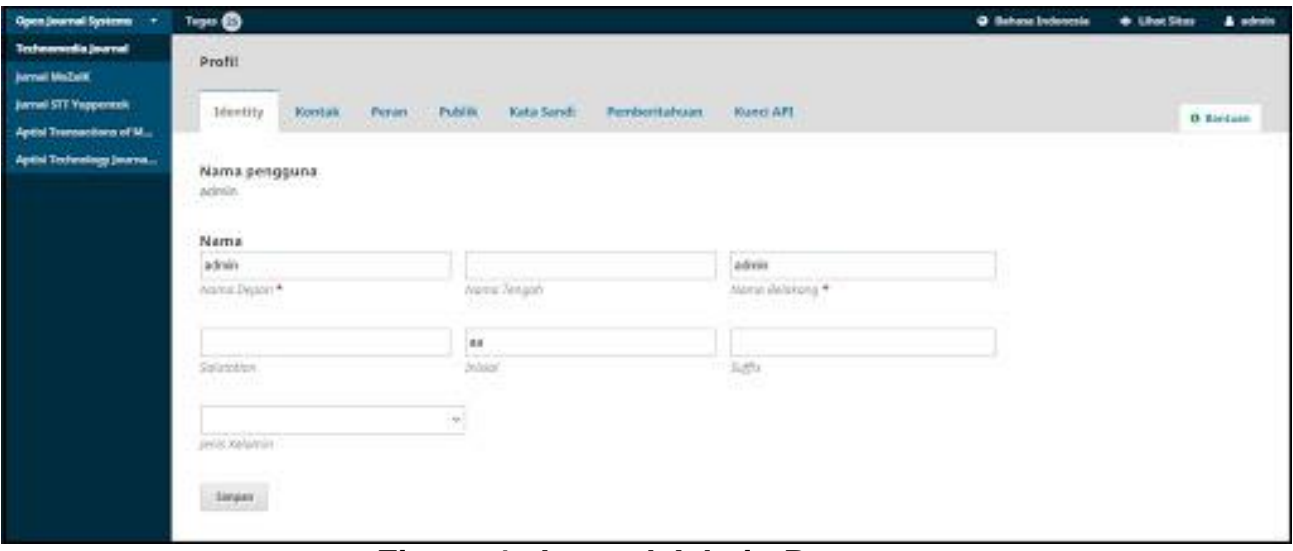

Figure 4. Journal Admin Page

The picture shows the page contained in the admin of the journal in the Open Journal System (OJS) version 3. After the admin journal has successfully entered, it will be directed to the profile section. This profile section functions to register users and their roles in the management process of the journal. Also on the left side there is a dropdown menu containing a collection of journals that have been created on the OJS system [24]. The picture shows 5 (five) journals as a whole which can be monitored by admin journals namely Technomedia Journal, Journal of Mosaic, STT Yuppentek Journal, Aptisi Transactions of Management, and Aptisi Technology Journal.

\section{Journal Editor's Page Display}




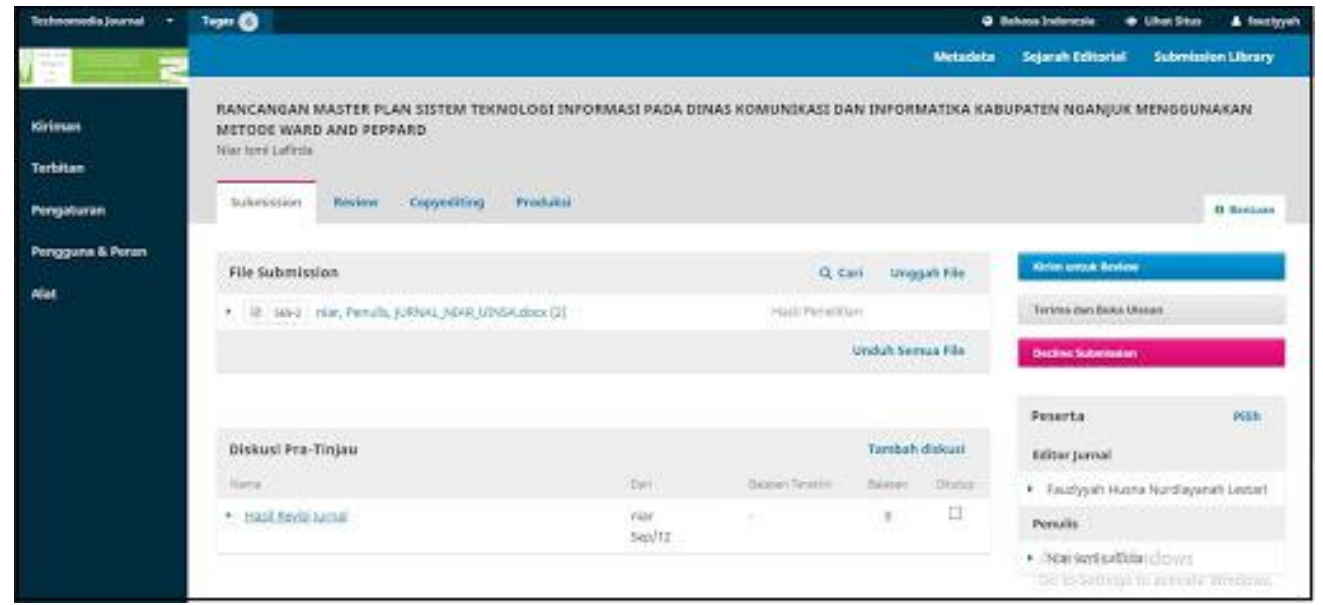

Figure 5. Journal Editor Page in the Submission Stage

The picture shows the process page for the journal editor in managing one of the scientific articles in the Open Journal System (OJS) version 3. After the journal editor has successfully logged in and selected one of the scientific articles to be checked by the editor, a page will appear as shown [25]. On this page, the management of scientific articles sequentially starts from the submission stage, review phase, copyediting stage to the production stage, all of which are handled by the journal editor. Before the manuscript of the scientific article enters the review stage, this is where the editor's role works to first check the suitability of the journal script template and check the level of plagiarism of the journal content [26].

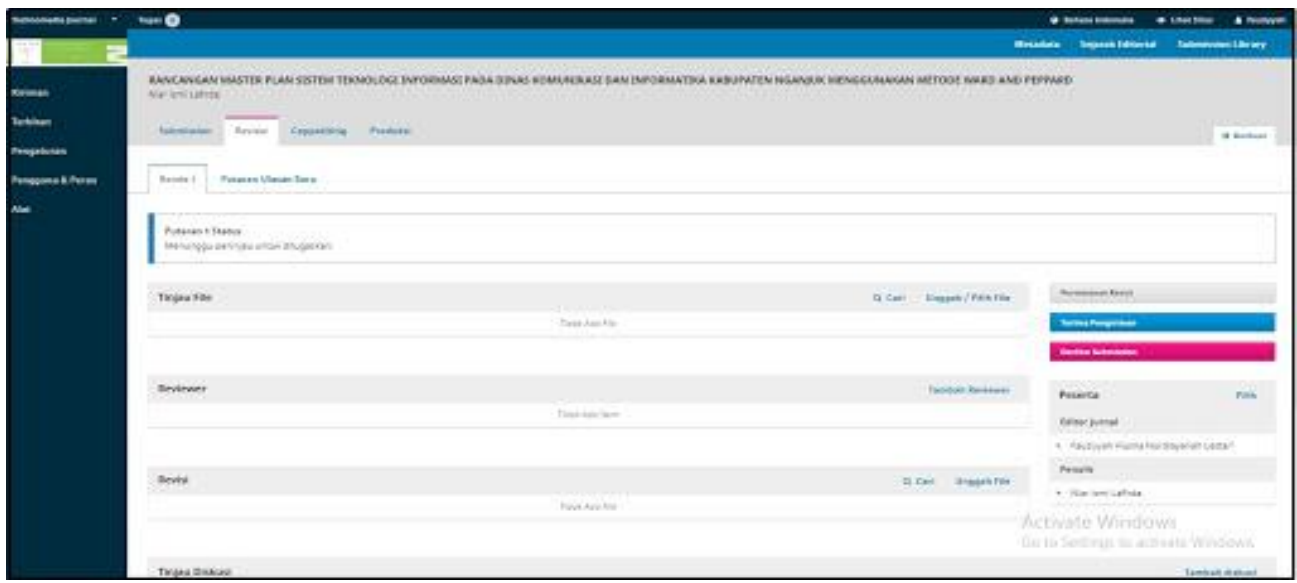

Figure 6. Journal Editor's Page in the Review Phase

The image still explains the appearance on the journal editor page where scientific articles begin to enter a new stage, namely review. On this page the role of the journal editor is to determine and choose who the reviewer will be assigned to check the scientific articles that have been sent [27]. Where after the journal editor checked the scientific article in the first stage, then the scientific article was thrown at the reviewer. In determining the journal editor reviewer can choose it in the reviewer column then click on the reviewer added on the page. 


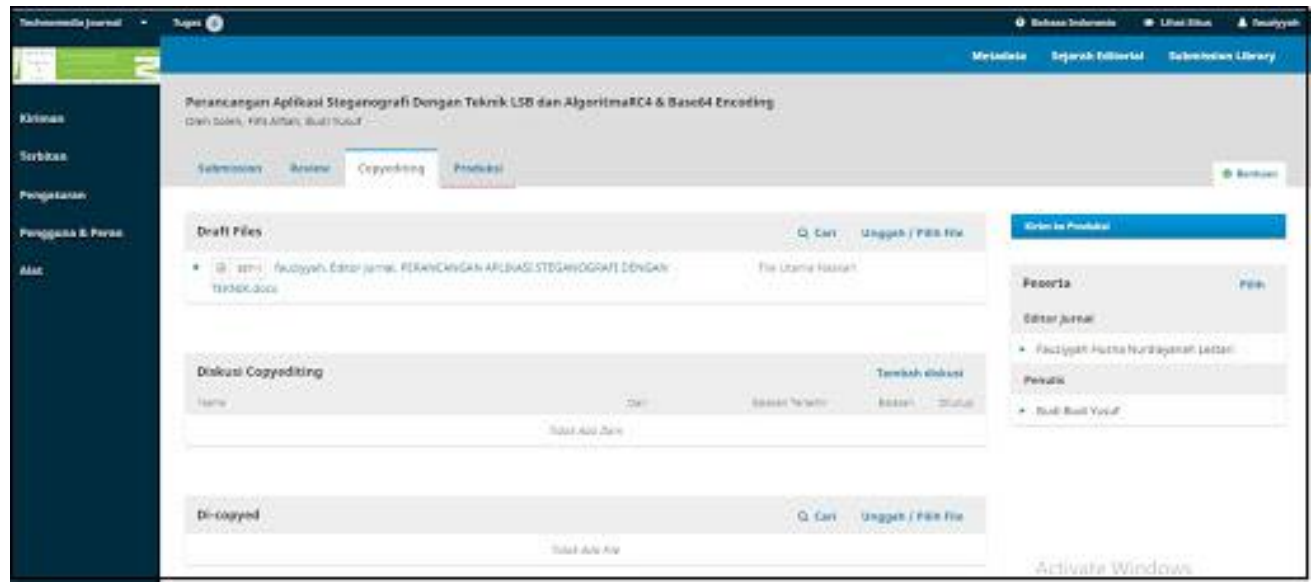

Figure 7. Journal Editor's Page in Copyediting Stage

After the scientific article is reviewed by a reviewer, which means that it has entered the review stage, the next step is the copyediting stage. At this stage the journal editor has received a revising submission of articles from the author (author) according to the direction of the reviewer and the article is uploaded or submitted by the journal editor in the draft files column [28]. Then it can be ascertained that the scientific article goes to the next stage, namely the production stage.

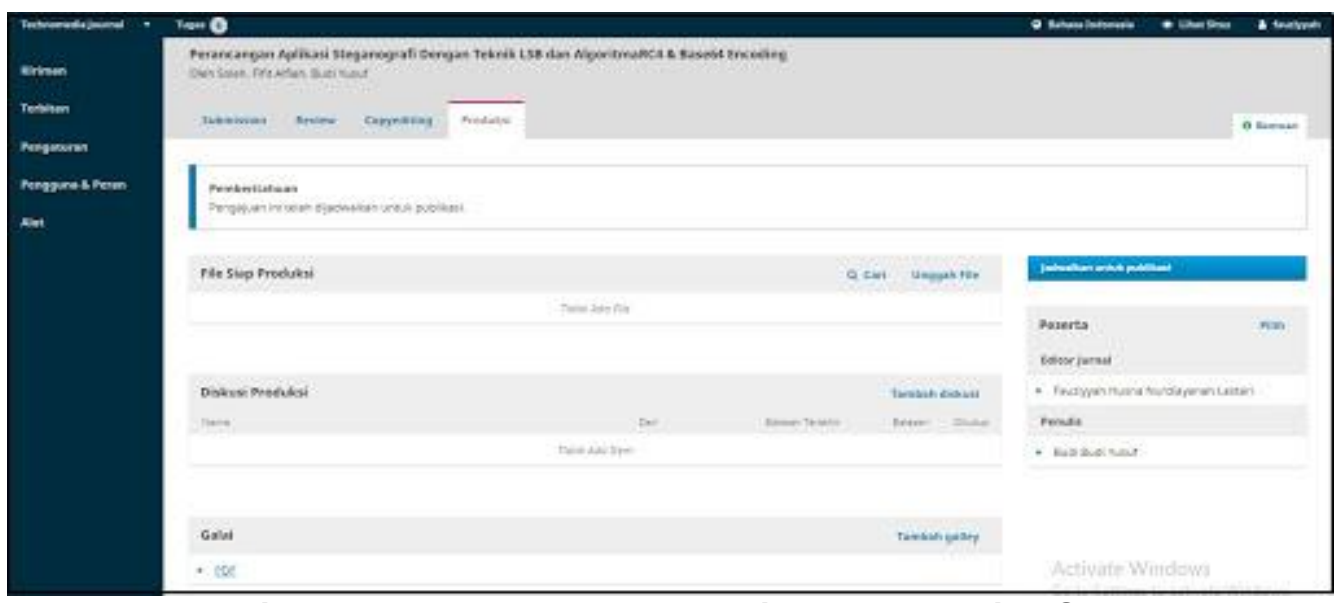

Figure 8. Journal Editor's Page in the Production Stage

The picture shows the page from the last step of managing the scientific journal by the editor, namely the production stage. After entering the copyediting stage where the editor of the journal has received a revising article from the author ready for publication, the journal editor uploads the scientific article in pdf format which is usually provided for download by other readers. Upload the scientific article in pdf form can be processed in the column add galleys on the page. Furthermore, the journal editor can immediately schedule the scientific article to be published in accordance with the volume of the publication of each journal [29].

\section{Review Page Views}




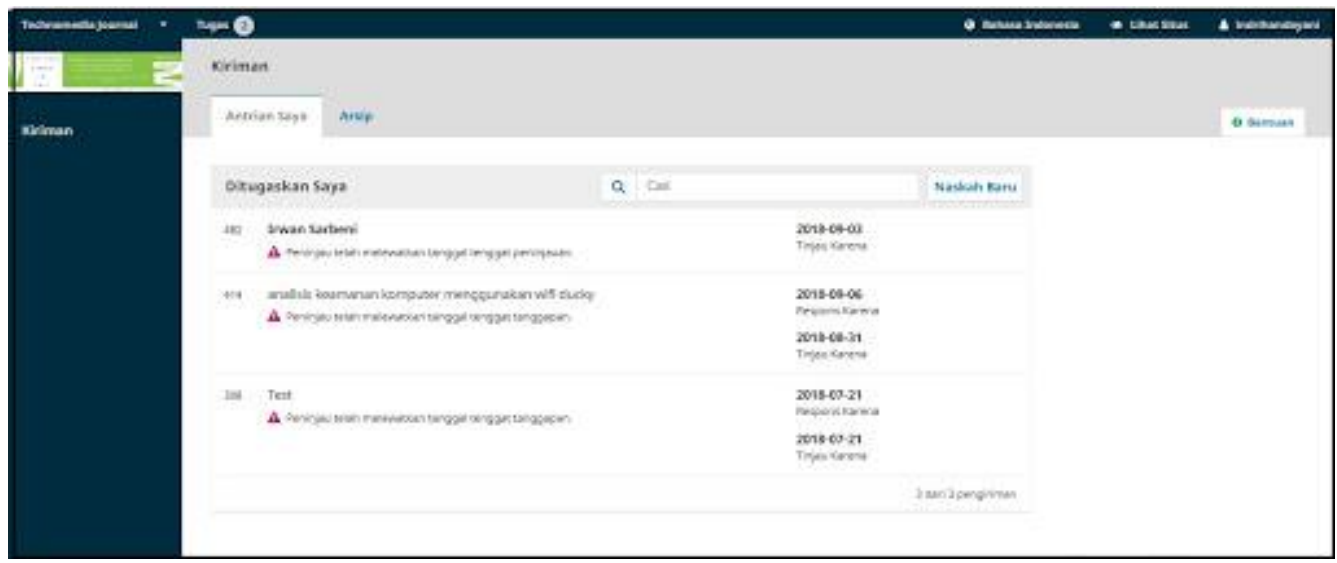

Figure 9. Review Page

The picture shows the existing page on the reviewer in receiving scientific articles sent from the journal editor. If the reviewer passes the assignment deadline determined by the journal editor then there is a notification that the reviewer has missed the review date [30]. In conducting this review the reviewer can download the scientific article script sent by the journal editor then can open the document and evaluate the scientific article content according to the reviewer's knowledge.

\section{Conclusion}

Based on the analysis and observation that has been done by conducting a trial directly on the journal management process using the Open Journal System (OJS) in the iLearning Journal Center (iJC) system, conclusions can be drawn as follows:

1. The process of managing scientific journals using the Open Journal System (OJS) is carried out in stages starting from the delivery of scientific articles conducted by the author (author), the process of checking by journal editors, sending scientific articles to reviewers, sending revised files, copyediting process, until entering the production phase all is done systematically according to the procedures in the Open Journal System (OJS) stage [31]. This means that in the process of managing this scientific journal there is no single step that is missed to be able to go to the next stage. Therefore, it takes a sufficient understanding of the process of managing this scientific journal from each of the roles directly involved in the process of this scientific journal so that it can be published in the Open Journal System (OJS) system.

2. The process of managing scientific journals that exist at Raharja College has now applied the Open Journal System version 3.1 software, especially in the iLearning Journal Center (iJC) which has a slightly different process view from the previous version and is devoted as a management media based scientific journal online. In the assignment process there is a notification or notification that is sent via email to their respective roles and there is an assignment link that directs directly to the Open Journal System (OJS) system page. In the Open Journal System (OJS) system, there is also a facility to do remainder related to tasks that must be carried out by each role if it will pass the assignment or review deadline.

3. With the stages of the management process that is automatically available in the system, it is expected that the process of managing scientific journals will be more effective and efficient and can provide better benefits in terms of setting scientific articles that are entered and selected according to the scope of research and criteria that meet the standards. each journal so that it can have a good impact on the quality of scientific journals. However, these steps must be understood by each role involved in the process of managing the journal how to use this system properly so that the activities of the scientific journal publication process can be implemented optimally.

\section{References}

[1] Rahardja, U., Aini, Q., \& Enay, N. (2017). Optimalisasi Dashboard pada Sistem Penilaian Sebagai Media Informasi di Perguruan Tinggi. Sisfotenika, 7(2), 167-176.

[2] Rahardja, U., Aini, Q., \& Thalia, M. B. (2018). Penerapan Menu Konfirmasi Pembayaran Online Berbasis Yii pada Perguruan Tinggi. Creative Information Technology Journal, 4(3), 174-185. 
[3] Aini, Q., Febriyanto, E., \& Pratama, D. (2017, August). PENERAPAN TEKNIK GAMIFIKASI DALAM BENTUK SENDING GIFTSUNTUK MENINGKATKAN TRAFFIC RANK. In SISITI: Seminar Ilmiah Sistem Informasi dan Teknologi Informasi (Vol. 5, No. 1).

[4] Handayani, I., Aini, Q., \& Oktavyanti, Y. (2015). Penggunaan RinfoCal Sebagai Aplikasi Pengingat (Reminder) Kegiatan Akademik Pada Perguruan Tinggi. CCIT Journal, 9(1), 13-26.

[5] Aini, Q., Rahardja, U., Moeins, A., \& Apriani, D. M. (2018). Penerapan Gamifikasi pada Sistem Informasi Penilaian Ujian Mahasiswa Untuk Meningkatkan Kinerja Dosen. Jurnal Informatika Upgris, 4(1).

[6] Rais, N. S. R., Supriati, R., \& Danti, S. I. (2018). Instalasi Open Journal System (OJS) Versi 3 Sebagai Pendukung Kegiatan Pengelolaan dan Publikasi Jurnal IImiah. Technomedia Journal, 2(2), 66-80.

[7] Handayani, I., Aini, Q., \& Sari, N. (2018). Pemanfaatan Sistem iJC Berbasis OJS Sebagai Media E-Journal Pada STISIP YUPPENTEK. Technomedia Journal, 2(2), 94-106.

[8] Darmalaksana, W., \& Suryana, Y. (2018). Korespondensi Dalam Publikasi Ilmiah. Jurnal Perspektif, 1(2).

[9] Darmalaksana, W. (2018). Organisasi Penanggungjawab Publikasi Hasil Penelitian.

[10] Yamin, M. (2018). Kebijakan Literasi Untuk Meningkatkan Produktivitas Publikasi di Perguruan Tinggi. JAS-PT Jurnal Analisis Sistem Pendidikan Tinggi, 2(1), $19-26$.

[11] Rahardja, U., Handayani, I., \& Wijaya, R. (2018). Penerapan Viewboard Technomedia Journal menggunakan sistem iLearning Journal Center pada Perguruan Tinggi. Technomedia Journal, 2(2), 78-89.

[12] Situmorang, M., \& Sihombing, K. (2018). STRATEGI MEMPERSIAPKAN MANUSCRIPT ARTIKEL YANG BAIK UNTUK PUBLIKASI PADA JURNAL ILMIAH BEREPUTASI. GENERASI KAMPUS, 10(2).

[13] Azizah, N., Suryana, E., \& Haris, H. (2017). Application of a Customer Based Data Monitoring Facility Online Accounting Software For Effectiveness Leadership at Higher Education. Aptisi Transactions of Management (ATM), 1(2), 93-100.

[14] Arribathi, A. H., Maimunah, M., \& Nurfitriani, D. (2017). Implementation System of Business Intelligence System In The Company. Aptisi Transactions of Management (ATM), 1(2), 143-149.

[15] Sunarya, A., Saptoro, A., \& Apriyani, D. (2017). Utilization Setting Menu To Build Company Accounting System In Web Based Accounting Online System. Aptisi Transactions of Management (ATM), 1(1), 1-10..

[16] Sudaryono, S., Sunarya, L., \& Maulani, G. (2017). Facility for Customizing Transaction Forms on Master Data Using an Online Accounting System Web For Work Efficiency Company. Aptisi Transactions of Management (ATM), 1(1), 19-26.

[17] Rahayu, N., Lestari, F. H. N., \& Aprilyani, U. T. (2017). Clothing Sales Information System WebBased:"Bluelight Distro". VOLT: Jurnal IImiah Pendidikan Teknik Elektro, 2(1), 55-62.

[18] Febriyanto, E., \& Yulianto, F. H. N. L. (2018). Penerapan Viewboard Rooster Berbasis Bootstrap Sebagai Penunjang Pelayanan iDuhelp! Pada Perguruan Tinggi. Jurnal IImiah Teknologi Informasi Asia, 12(2).

[19] Rahardja, U., Harahap, E. P., \& Pratiwi, S. (2018). Pemanfaatan Mailchimp Sebagai Trend Penyebaran Informasi Pembayaran Bagi Mahasiswa Di Perguruan Tinggi. Technomedia Journal, 2(2), 38-51.

[20] Rahardja, U., Dewi, E. N., \& Lutfiani, N. (2017). Peningkatan Rank Webometrics Menggunakan Metode Inbound Dan Outbound Pada Perguruan Tinggi. Sisfotenika, 7(1).

[21] Handayani, I., Aini, Q., \& Oktaviani, F. (2016). PENERAPAN SISTEM VALIDASI JURNAL DI PESSTA+ SEBAGAI PENILAIAN ARTIKEL ILMIAH DALAM MENDUKUNG KEGIATAN CIVITAS AKADEMIKA. CSRID (Computer Science Research and Its Development Journal), 8(3), 177190.

[22] Rahardja, U., Aini, Q., \& Sulastrini, L. R. (2017). Penerapan Inbound Official Site Sistem Informasi Untuk Meningkatkan Rank Webometrics. Technomedia Journal, 1(2), 106-117.

[23] Rahardja, U., Aini, Q., \& Meytasari, R. (2017). Pemanfaatan Fungsi Etalase Artikel Untuk Meningkatkan Traffic Rank Website ZPreneur. Technomedia Journal, 1(2), 75-89.

[24] Handayani, I., Febriyanto, E., \& Solichin, K. R. P. (2018). Penerapan Viewboard Sebagai Media Informasi Sidang Skripsi Pada PESSTA+ di Perguruan Tinggi. Technomedia Journal, 2(2), $52-$ 62.

[25] Rahardja, U., Lutfiani, N., \& Alpansuri, M. S. (2018). Pemanfaatan Google Formulir Sebagai Sistem Pendaftaran Anggota Pada Website Aptisi. or. id. SISFOTENIKA, 8(2), 128-139. 
[26] Rahardja, U., Moein, A., \& Lutfiani, N. Leadership, Competency, Working Motivation and Performance of High Private Education Lecturer with Institution Accreditation B: Area Kopertis IV Banten Province. Man India, 97(24), 179-192.

[27] Raharja, U., Lutfiani, N., \& Wardana, W. S. (2018). Penjadwalan Agenda Pelaksanaan Tridharma Perguruan Tinggi Secara Online Menggunakan Google Calendar.

[28] Rahardja, U., Aini, Q., \& Santoso, N. P. L. (2018). Pengintegrasian YII Framework Berbasis API pada Sistem Penilaian Absensi. SISFOTENIKA, 8(2), 140-152.

[29] Rahardja, U., Aini, Q., \& Faradilla, F. (2018). Implementasi Viewboard Berbasis Interaktif Javascript Charts Pada Sistem Penilaian Perkuliahan. Jurnal IImiah Teknologi Informasi Asia, 12(2), 91-102.

[30] Rahardja, U., Aini, Q., \& Faradilla, F. (2018). IMPLEMENTASI VIEWBOARD BERBASIS INTERAKTIF JAVASCRIPT CHARTS PADA WEBSITE E-COMMERCE PERGURUAN TINGGI. Jurnal Dinamika Informatika, 7(2), 1-17.

[31] Rahardja, U., Aini, Q., \& Khoirunisa, A. (2017). Implementasi Business Intelligence Menggunakan Highchart pada Sistem Penilaian Absensi berbasis YII Framework. CSRID (Computer Science Research and Its Development Journal), 9(2), 115-124. 